\title{
Account of a Foretold Death: Analysing the Response to the Pandemic in the Schools of Castellón (Spain)
}

\begin{abstract}
Alicia Chabert
Universitat Jaume I

Correspondence concerning this article should be addressed to Alicia Chabert, Universitat Jaume I, Avinguda de Vicent Sos Baynat, s/n, 12071 Castelló de la Plana, Castelló, Spain. E-mail: chabert@uji.es

The Covid-19 pandemic has had a profound impact on education, not only due to its dramatic interruption of the school year (2019-2020) but also its potential effect on many aspects regarding teaching in the future. In particular, focusing on Spain, this year's events have also highlighted the lack of digital resources and preparedness of the schools, which has resulted in some difficulties when adapting to the new circumstances. In this paper, the author will start by explaining how the digital competence has developed into an indispensable competence for learning in the past decade, which the current global pandemic has emphasised even more. As a consequence of this pandemic, schools and education centres remained closed from March 2020 to the end of the academic year in Spain. This article focuses on the importance of technology accessibility and digital competence in language learning, as well as the way it was overlooked in practice. The immediate response from the Ministry of Education will be analysed and compared to the way teachers and schools in the Valencian region (Spain) supported the students during the enforced lockdown in the last trimester of the academic year in primary school. For this, teachers in four schools in Castellon (Valencian region) were interviewed, and drawing from their replies, the current reality of the use of technology in primary school will be examined and compared to the national guidelines and frameworks provided for educators. Questionnaires were used and analysed using a qualitative approach, while comparing the current situation to the expected response according to the educative guidelines.
\end{abstract}

Keywords: digital competence, communicative competence, pandemic, Covid-19, language learning, school curriculum

\section{Introduction}

The novel disease Covid-19 has become the fifth documented pandemic since the flu pandemic in 1918 (Liu et al., 2020). While it was first reported in Wuhan, China, around December 2019, it rapidly spread worldwide affecting most of the planet by March 2020. Because of the aggressive - and potentially deadly - nature of the symptoms and high risk of contagion, the world shut down in its majority, resorting to long quarantine periods of isolation. Consequently, as well as many other sectors, education was greatly affected. Some classes were cancelled, and others moved to online platforms. Countries around the world provided internal general guidelines to their educators, with restrictions and policies for the schools to follow and provide online support to the students. And Spain was no exception. For a long time now, digital competence had become vital to educators and learners, finding its place among the essential learning competences of the 21st century ( Ferrari et al., 2012; van Laar et al., 2017). Yet, this competence is linked to different contextual factors.

The objective of this paper is to discuss the essential role of digital competence in education, along with the factors involved in its use, within the context of the pandemic. This paper reveals the contrast between the unpreparedness of schools in terms of integrating this competence, which has been highlighted dramatically in such a moment of necessity, and the confusing guidelines received from the governmental institutions. Throughout this paper the author will focus on the experiences of English language teachers during the pandemic, starting with an analysis of the concept of competence and digital competence involved in language learning; following with its inclusion in the curriculum; and, finally, examining real teacher experiences along with data on the schools' responses to the pandemic. 


\section{ACCOUNT OF A FORETOLD DEATH}

The aim of this research is to draw attention to the inconsistencies between guidelines and practice in the school setting, along with the need of integrating digital competence in language learning from a realistic perspective, taking into account school resources and students' access to technology.

\section{Literature Review}

\section{Competences}

The concept of 'competence' has been theorised and described in education time and time again. Nevertheless, the coining of the term is generally credited to Chomsky, along with the dichotomy between competence and performance (Chomsky, 1965). His intention was to depart from the Saussurean distinction between langue and parole, and proposed a distinction between linguistic competence, understood as the knowledge underlying the necessary skills to use a language, and performance as the actual use of language in specific situations. While Chomsky was the first to define this concept, a very complete definition of what constitutes a competence is provided by Martínez-Carrasco (2017, p. 154) ${ }^{1}$ :

A polyhedral, complex construct composed of a dynamic cluster of forming elements that apply to specific, situated work conditions. Knowledge, skills, behaviour, and attitudes, whose weight in the overall competence construct may vary according to the particular task to be performed, play the most relevant role in the said cluster.

Such is the complex and varied nature of the concept of competence that defining the competences involved in language learning has been one of the main foci of Second Language Acquisition. From purely linguistic competences, the focus shifted towards interaction and communication. In fact, the communicative competence has been on the spotlight for decades, going from Hymes (1972), through Celce-Murcia (1995), and Dornyei (2009), among many others. It has become one of the key competences according to the most used language learning framework worldwide, the Common European Framework of Reference for Languages: Learning, teaching, assessment ${ }^{2}$. This competence, however, has now developed into a macro-competence encompassing different sub-competences. Chabert and Agost (2020) provide a visual interpretation of the communicative competence and its sub-competences from a plurilingual perspective, which is provided below for further reference and illustration of the competences involved in language learning:

\section{Figure 1}

Competences Involved in the Communicative Model

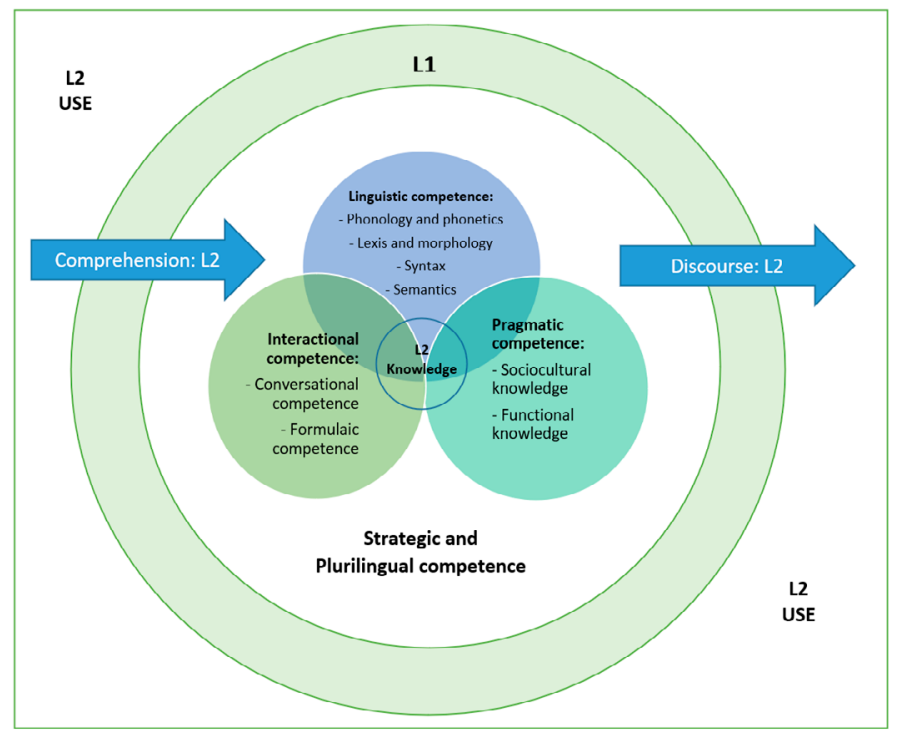

${ }^{1}$ Martínez-Carrasco, R. (2017). Epistemological approaches to legal translation education: A situated account [Universitat Jaume I]. https:// dialnet.unirioja.es/servlet/tesis?codigo=13683

2 Council of Europe. (2018). Common european framework of reference for languages: Learning, teaching, assessment. Companion volume with new descriptors. Council of Europe Publishing, Strasbourg, available at https://rm.coe.int/cefr-companion-volume-with-new-descriptors-2018/1680787989 
Note. Competences involved in the communicative model in LX learning. Reprinted from "Communicative language teaching: Is there a place for L1 in L2 learning?”, by A. Chabert and R. Agost, , 2020,European Journal of Language Policy, 12(1), p. 62. Copyright 2020 by Liverpool University Press. Reprinted with permission.

In the above illustration (Figure 1), the different competences involved in Additional Language Learning can be observed, which, in the case of this study, would refer to English teaching. Nevertheless, these competences do not account for the limitations brought by the pandemic, which relied on a more computer-based learning.

By the end of the twentieth century, computer-assisted language learning (CALL) was brought to the spotlight thanks to the progress in technology. According to Chapelle (2009), already at the start of the 1990s, computer technology began to be considered something that teachers could add to other learning materials and activities. The role of technology started to change and to add dimensions to communicative competence. In line with this, she stated that "anyone who uses technology to produce, comprehend, and interact in an L2 [second language] today is easily convinced that communicative competence is tied to the technologies chosen and used" (Chapelle, 2009). Yet, despite the direct link with communicative competence, the transversality of digital competence transformed this construct into an independent essential skill of the twenty-first century rather than a sub-competence of communicative competence.

Digital competence is an evolving concept, as it is intrinsically interconnected to the development of technology. A study from the University of Helsinki analysed 76 educational research articles attempting to define digital competence and suggested that it consists of different competences and abilities (Ilomäki et al., 2016): technical competence, the meaningful use of digital technologies in every life aspect, the ability to evaluate technologies, and the motivation to participate in digital culture. Ilomäki et al. (2016, p. 657) define digital competence as an emerging and broad connecting concept that "operates as a loosely defined boundary concept (and a transdiscursive term) amongst policy-makers, practitioners and researchers." However, the European Commission has not only defined it, but has created a framework to be implemented in European policy. According to the Commission, a lack of digital skills has a direct impact on people's chances in life. Consequently, this framework was created in order to identify and describe the main competences and skills involved in digital competence. This way, the DigComp project was launched with the aim of identifying the key components of digital competence, developing its descriptors to feed a conceptual framework and propose guidelines (Ferrari, 2012). This framework was to be implemented in multiple domains including education and employment, with DigCompEdu focusing on a framework specific to educators (Redecker \& Punie, 2017).

Due to the current technological requirements, teachers are required, now more than ever, to first develop their digital competence to help students become digitally competent. For this, DigCompEdu provides the 22 elementary competences organised in 6 areas that are illustrated on Figure 2 below:

- Area 1: Related to the professional environment of educators

- Area 2: Focused on the digital resources, their use, creation and management

- Area 3: The use of digital technologies for teaching and learning

- Area 4: The use of digital strategies and technologies for assessment

- Area 5: Empowering learners through the use of technology

- Area 6: Focused on specific pedagogic competences involved with digital competence 
Figure 2

Educators and Learners Competences Involved in Digital Competence

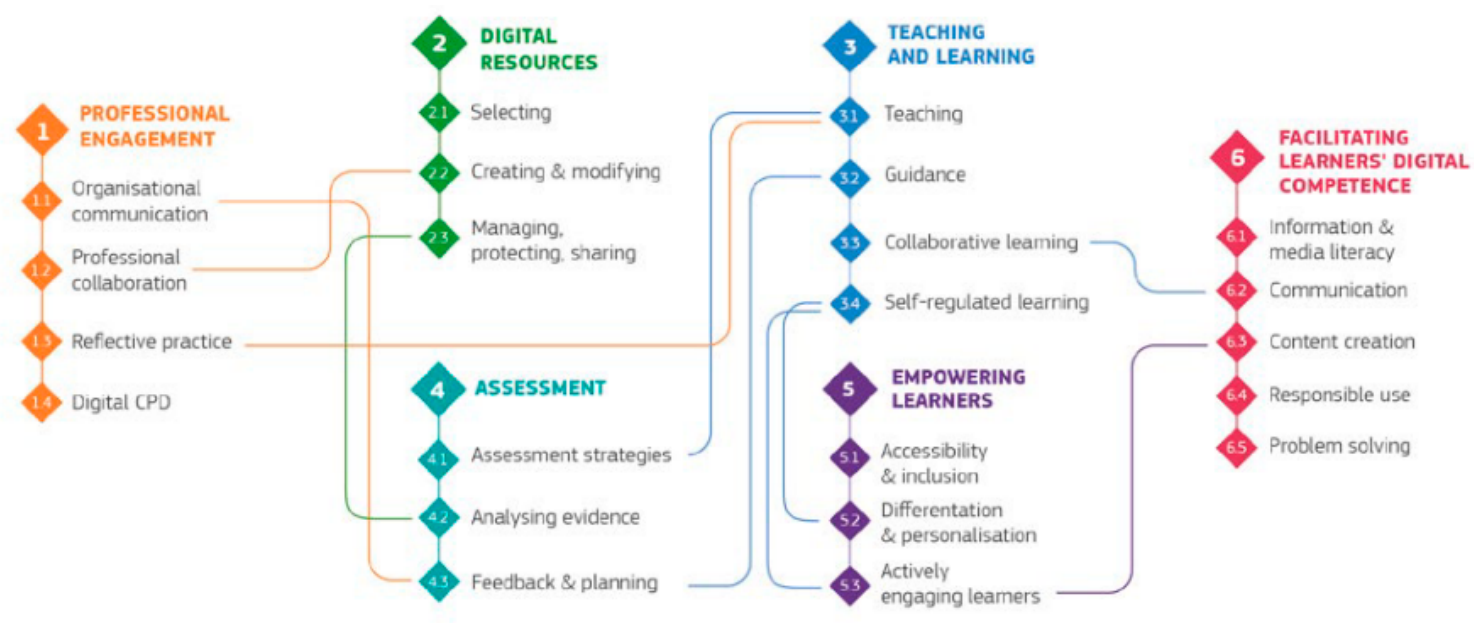

Note. Diagram on the learners and educators' competences Involved in Digital Competence. From European framework for the digital competence of educators, by C. Redecker, and Y. Punie, 2017, p. 8. Copyright 2017 by Publications Office of the European Union. Reprinted with permission.

The above competences (Figure 2) reflect the areas involved in digital competence and required in digital learning. From this table, it can be observed that, if any of the areas fail (such as the digital resources due to a lack thereof), digital learning and its competences will suffer as a result.

Not long after this project, the Ministry of Education launched the Common Framework for Teacher Digital Competence based on DigComp, and its use was agreed between the State and Regional governments ${ }^{3}$. This framework was focused on the continuous development of educators in the competences involved in digital competence. Throughout the document it is proposed to promote the implementation of the relevant guidelines that would allow the acknowledgment and evaluation of the educators' digital competence according to the common framework, as well as promoting the implementation of reference national digital systems ${ }^{4}$. According to this, and the Spanish Curriculum analysed below, it would be safe to assume that, for educators to be able to develop and use their digital competence, education centres would have to provide the educators with the necessary platforms and resources. Nevertheless, the guidelines are mainly focused on the teacher's knowledge, skills, development and strategies to prepare for the digital world, somehow underestimating the need for a good digital infrastructure.

\section{Information and Communication Technology in the Spanish Curriculum}

Since its reform in 2013, the Spanish Education Law that was current during the school year 2019-2020 (LOMCE 5 , for its acronym in Spanish) emphasised three main foci ${ }^{6}$ : ICTs (Information and Communication Technology), Plurilingualism, and the modernisation of Professional Training studies, which are wellestablished European key points (Breidbach, 2003; Council of Europe, 2001, 2008; European Commission, Council of Europe, European Economic and Social Committee, \& Committee of the Regions, 2018). This law also highlighted digital competence as a $21^{\text {st }}$-century key competence, according to the report from the

\footnotetext{
3 Spain is a nation divided in autonomous regions, hence, while the State provides general guidelines to be followed at a national level, each of the regions have certain freedom within those parameters and regulate education, resulting in some differences across the country.

4 INTEF. (2017). Marco común de competencia digital docente. - Septiembre 2017 [Common framework for digital competence in education. - September 2017]. https://aprende.intef.es/sites/default/files/2018-05/2017_1020_Marco-Común-de-Competencia-Digital-Docente.pdf

5 LOMCE (Ley Orgánica 8/2013, de 9 de diciembre, para la mejora de la calidad educativa). BOE 2013. BOE-A-2013-12886

6 While these foci still remain, there was a new reform published on the 28th of December 2020 (LOMLOE), which focuses on the development of competences, inclusivity, and, among other changes, eliminates final tests in primary and secondary school. (BOE, 2020a)
} 
European Commission? ${ }^{7}$ The LOMCE recognised the impact of new technologies and globalisation in the current way of learning and communicating stating that ${ }^{8}$ :

The general implementation of Information and Communication Technologies (ICTs) into the educational system, which will take into account the principles of universal accessibility for everyone, will make it possible to personalise education and adapt it to the needs and pace of each student. [Own translation]

The above section starts with the principle of accessibility and adaptability of ICT resources, which follows with an emphasis on the importance of a methodological change in teaching and the digitalisation of resources, all while urging the schools to adhere to their budgets, as it can be read on the next section (BOE, 2013, p.10):

Information and Communication Technologies (ICTs) will be a fundamental piece to carry out the methodological change that will lead us to achieve the objective of improving the educational quality. [...] Having evaluated the above, it is essential that the school digitalisation model chosen is economically sustainable, and that it focuses on the creation of a national digital ecosystem that allows the regular development of the options for each educational administration. [Own translation]

This regulation continues by focusing on virtual environments and digital platforms, as well as claiming that accessible platforms will be available for the whole education community.

\begin{abstract}
Virtual learning environments used in public schools will facilitate the implementation of specific educational plans designed by teachers to achieve specific curriculum objectives, and should contribute to the extension of the concept of the classroom in time and space. [...] The Ministry of Education, Culture and Sports will offer digital and technological platforms accessible by the entire educational community, which may incorporate didactic resources provided by the educational administrations and other agents for their shared use. The resources should be selected according to parameters of methodological quality, adoption of open standards and availability of sources that facilitate their dissemination, adaptation, reuse and redistribution and will be recognised as such. [Own translation]
\end{abstract}

Yet, despite the statement on "general online platform availability", the PISA 2018 study from the OECD ${ }^{9}$ shows that only $51.5 \%$ of educative centres use online platforms and only $53.3 \%$ of schools consider the number of digital devices with internet access as sufficient.

A year after the 2013 Reform, an update of the primary school national curriculum included digitalisation and the use of technology throughout the curriculum as part of the transversal skills and competences required in all subjects. In fact, Article 10 in the BOE of $2014^{10}$, focuses on transversal elements and states that:

Without prejudice to their specific treatment in some of the subjects of each stage, reading comprehension, oral and written expression, audiovisual communication, Information and Communication Technologies, civic and constitutional education and projects will be included on in all subjects. [Own translation]

However, when focusing on the curriculum for foreign language learning it can be observed that there are no direct guidelines for ICTs, other than a general statement requesting their integration in the learning process. One of the main criticisms against these guidelines is the fact that ICTs are expected to be included in school subjects and that educators are required to be digitally knowledgeable; but, they do not seem to consider the actual technological resources available to students in and out of the schools.

\footnotetext{
7 European Commission. (2008). Improving competences for the 21st century: An agenda for European cooperation on schools. In $\operatorname{COM}(2008) 425$ final. https://eur-lex.europa.eu/LexUriServ/LexUriServ.do?uri=COM:2008:0425:FIN:EN:PDF

8 See page 9 in BOE-A-2012-5403. Ley Orgánica 8/2013, de 9 de diciembre, para la mejora de la calidad educativa, 1 [Organic Law 8/2013, of 9 December, for the improvement of the quality of education, 1] (2013). https://www.boe.es/diario boe/txt.php?id=BOE-A-2012-5403

9 OECD. (2020). PISA 2018 Results (Volume V): Effective policies, successful schools, PISA, OECD Publishing, Paris, https://doi.org/10.1787/ ca768d40-en.

${ }^{10}$ BOE-A-2014-2222. Real Decreto 126/2014, de 28 de febrero, por el que se establece el currículo básico de la Educación Primaria, Boletín Oficial del Estado 19349 [Royal Decree 126/2014, of 28 February, establishing the basic curriculum for Primary Education, Official State Gazette 19349] (2014).https://www.boe.es/buscar/doc.php?id=BOE-A-2014-2222
} 
While the relationship between language learning and technology has been long and fruitful (Trujillo Sáez, Salvadores Merino, \& Gabarrón Pérez, 2019), access to new devices and resources has meant that the use of technology in language education continues to be in a constant state of development. Yet, the reality is that the theory does not seem to go hand in hand with the practice, as it can be observed in the response to the pandemic in Spain.

\section{Response to a Pandemic}

It was only when the pandemic broke out back in March 2020 that the real use of technology in the classroom was put to the test. On the $14^{\text {th }}$ of March of 2020, the State of Alarm was declared in Spain, which closed schools and required educators to continue the third semester of the school year online. The national Ministry guidelines had to adapt to Covid-19 publishing an adapted legislation in $2020^{11}$, stating that educative centres would identify the students who were not able to connect online and prepare plans to achieve their connexion to education in order to ensure they could continue learning as soon as possible. This order also asserted that the Administration, as well as education centres, would identify the students lacking digital media and would increase the availability of technological resources to be lent to these students. In regard to the curriculum, the educators, along with the schools, were advised to develop tools and continue classes online so that the students were able to continue learning from home. As observed above, according to the law of 2013 technological platforms would be accessible by the entire educational community. However, most of the schools did not have, by the start of 2020, an online platform and the Ministry of Education provided a very limited number of online resources to teachers.

The objective of this paper is to examine the inconsistencies between guidelines received by the schools during the Covid-19 pandemic and actual experience from the teachers during that period. This research will highlight the need of integrating digital competence in language learning from a realistic perspective, taking into account school resources and students' access to technology. Having reviewed the current literature on competences, in particular on digital competence and its position in the Spanish curriculum, the author analyses the teachers' response and experience during lockdown in 2020. This is a small-scale research paper focused on a reduced sample, however its purpose to highlight the differences and lack of guidance in different schools even in such a small sample is testimony to the need for a better understanding of the need for technology in education in the future.

\section{Materials and Methods}

\section{Research Design}

In order to carry out the research, the author followed a qualitative method using open-ended question interviews, that is, using semi-structured interviews where the respondents had to answer pre-set open-ended questions, and analysed the data based on grounded theory. A questionnaire was created online using Google Forms, which was shared to the teachers via e-mail. This questionnaire had a Spanish and Valencian version, and both were sent to each teacher so that they could choose the language they would like to answer in. The same questions were asked to all participants, so that the interviews could be more easily analysed and compared. This approach was particularly useful to get the story behind the participant's experiences. Given the length limitation on this paper a summary of the interview replies of the teachers that participated in the study was provided.

\section{Participants}

The sample was focused on English language teachers of four different schools. In order to acquire specific data from the area of Castellón, a small questionnaire was shared with teachers of English in fifth and sixth year of

\footnotetext{
${ }_{11}$ BOE (2020b). BOE-A-2020-4609. Orden EFP/365/2020, de 22 de abril, por la que se establecen el marco y las directrices de actuación para el tercer trimestre del curso 2019-2020 y el inicio del curso 2020-2021, ante la situación de crisis ocasionada por el Covid-19., [Order EFP/365/2020 of 22 April establishing the framework and guidelines for action for the third quarter of the 2019-2020 academic year and the start of the 2020-2021 academic year, in view of the crisis situation caused by Covid-19.] No. EFP/365/2020, BOE-A-2020-4609 (2020). https://www.boe.es/eli/es/o/2020/04/22/efp365/con
} 
four primary schools (one teacher was interviewed in each school). The schools were located in very different areas: the first one (School A) belonged to a humbler district of the city of Castellón, whereas the second one (School B was located in a wealthier area, where most of the families belonged to an upper-middle class status. The third one (School C) was located in a regular middle-class area and contained a high number of students per class. Lastly, the fourth one (School D) in the small town of Borriol, which belongs to the Castellón area, but it is located $10 \mathrm{~km}$ towards the mountains.

All four schools had female English teachers aged between 30 and 45, who were comfortable with digital technology.

\section{Instruments}

This paper uses two main instruments: a questionnaire to gather the personal experiences from teachers in schools in Castellon and a review of current education guidelines.

The author examined the current national and regional guidelines along with the Common European Framework of Reference for Language Learning (CEFR, henceforth) following a comparative legal research methodology. With the purpose of getting the full picture, the CEFR is examined as a framework according to the current learning guidelines and education laws that have been developed. Consequently, the education laws in Spain that were current during the year $2020^{12}$ are contextualised along with the political measures implemented during lockdown.

In terms of the questionnaire, the following questions were asked (the below have been translated into English):

- During the State of Alarm implemented in Spain from the $14^{\text {th }}$ of March to the $21^{\text {st }}$ of June, were the classes fully cancelled or were they continued online?

- $\quad$ If you continued the classes online, please tell us about your experience.

- Did your students have technological access?

- $\quad$ Do you think the pandemic situation had a direct impact on the English level of the students?

- Given the fact that the classes were online, did you focus on a specific competence more than another one?

- Bearing in mind that you teach English but you were limited by technology, did you have to use your mother tongue (Spanish or Valencian in this case) more than you would usually do?

\section{Procedure}

Grounded theory methods (Corbin \& Strauss, 2008) were used to shape these qualitative interviews via questionnaire. Thanks to the ongoing contact with several schools during the pandemic for ongoing research on English learning, it soon became apparent that each of the schools were facing the pandemic differently. Following inductive reasoning, the author focused on the specific points affecting the different approaches in each of the schools, namely technological access, and applicable legislation. These strategies led to studying concrete realities and rendering a conceptual understanding of them (Khan, 2014). The open-ended questions allowed an exploration of the teachers' subjective experience during the pandemic within resources and guidelines constraints that were analysed for further contextualisation.

\section{Analysis}

From the questionnaires common themes were extracted: access to technology (and digital resources available), as well as the confusing or inaccurate guidelines received from different education institutions. The teachers' experience was complemented with an analysis of the curriculum and guidelines, as well as the subsequent review of literature on the digital divide in Spain and the new Government programs that acknowledge the circumstances experienced by the teachers and aim to prevent this in the near future. The analysis of the

\footnotetext{
${ }_{12}$ BOE (2020a). BOE-A-2020-17264 - LOMLOE, Ley Orgánica 3/2020, de 29 de diciembre, por la que se modifica la Ley Orgánica 2/2006, de 3 de mayo, de Educación. [Organic Law 3/2020, of 29 December, which amends Organic Law 2/2006, of 3 May, on Education] https://www. boe.es/eli/es/lo/2020/12/29/3
} 
national guidelines also brought to light the main focus on the teachers' digital competence, rather than the students' access to technology and their preparedness for distance learning.

\section{Results and Discussion}

In School A, the teacher confirmed that no classes were carried out due to the lack of resources. She also pointed out how this fact increased inequalities between children and reduced their oral and listening skills on the new academic course. She confirmed that tasks were given to the students on a weekly basis via e-mail. This school did not have an educative platform, so any activities or doubts were solved via e-mail. Consequently, not all competences were able to be developed, with the focus being kept on written activities only, so that they could be provided via e-mail. This had a direct effect on the students' English language development. Likewise, the school did not have the means to provide devices to vulnerable students either.

In School B, however, classes continued fully online, since this school did have an online platform and the students had access to technology at home. However, the teacher confirmed that the classes were very different to what was initially programmed. From the national guidelines, the teachers were advised not to progress on any content and to review for the rest of the academic year. This teacher confirmed to try and work on all language learning skills and stated that there was no difference in language use of the mother tongue in the English classroom. Despite the fact that no new content was learnt, the students continued practising English and this teacher felt like the quarantine did not have a significant impact on the students' learning.

In School C, in contrast, the classes stopped but a blog was created as a way of providing a virtual classroom. However, the teacher complained that the attendance to the 'virtual' classroom was very difficult to control and, in the end, it became more of an asynchronous solution. She mentioned that, in order to teach online a good platform for classroom management was necessary, as well as different tools. This school was able to provide some students with tablets so that they were able to have technological access. Yet, she confirmed that some students did not do anything at all, while others were in regular contact until the end of the school year. She stated that online classes, in her opinion, do not work in primary school for long periods of time. Also, because the classes are big and students are reluctant to participate, some students were feeling demotivated by the situation. According to this teacher, the students that did not follow the online class did lose a lot of fluency and their English level was reduced.

Lastly, in School D the teacher taught adapted content online (via Zoom) but confirmed she was unable to progress with the curriculum in accordance with the national guidelines provided. In this school, the classroom groups were much smaller due to the small size of the town. The teacher confirmed she focused more on writing and reading comprehension, rather than listening and speaking. She also stated that: 'Obviously, this school interruption has resulted in increasing level inequalities among children and reduced oral and listening skills'. She mentioned that they had online meetings daily to solve queries and send more homework. Those final three months at the end of the academic year were used to review the content the students had studied until that point, which helped them consolidate vocabulary and structures.

In relation to the competences involved in language learning including the correct implementation of digital competence, it was observed that the learners' competences could not be developed in their totality during the pandemic. This was the result of a lack in resources from both students and the schools, and it also led to a divide among the learners in terms of language levels.

All in all, the situation of each school appears to be more limited by the school resources than the actual digital competence of the teacher, which seemed to be the focus before the pandemic, based on the European and current Spanish national guidelines and frameworks.

\section{The Digital Divide}

Consequently, the focus must shift the digital divide, which includes factors such as the unequal opportunity to access information, knowledge and education (Serrano-Santoyo \& Martínez-Martínez, 2003). The digital divide is characterised by two main factors: not being able to use ICTs (which was the main focus prior to the 
pandemic) and the lack of access to technology either at home or school. The lack of access to ICT or its poor use result in exclusion (Cañón Rodríguez et al., 2016), which can be observed on one of the fragments from the account of the teacher in the first school, which is provided below in Spanish (original) and its translation:

'Para dar clase a distancia es necesaria una buena plataforma, programas de edición y ordenadores en condiciones. Todo esto no existía para primaria... Algunos alumnos no tenían material adecuado para seguir las clases. Los alumnos que siguieron las clases poco a poco se iban desmotivando, sus circunstancias de encierro tampoco favorecían la motivación.Los que no siguieron las clases, han perdido mucho.'

('In order to teach from home, you need a good platform, editing software and computers. All this did not exist in primary school...Some students did not have adequate material to follow the classes. The ones who followed the classes gradually became demotivated; their confined circumstances did not favour motivation either.Those who didn't follow the classes have lost a lot [of knowledge]')

In terms of resources, the four schools participating in this study had interactive whiteboards in the classroom, but only two of them had devices available for the students to take home in case of need and only one of them had an actual online platform, while the other three depended on the teachers to prepare and provide the necessary resources to the students.

A national statistical analysis of 2020 shows that $75.3 \%$ of household in Spain situated in areas with a smaller population than 10,000 had at least one device per home (this includes PC, tablets, laptops and similar gadgets), while in the household located in cities of 100,000 inhabitants or more the percentage was higher than $85 \%^{13}$. This already presents an inequality based on the area. While in the analysed case the difference between rural and urban areas did not appear to affect the access to technology, the difference between economically diverse areas played a major role.

\section{Learning from Mistakes}

While the conclusion above can appear to be anecdotal, it can be extrapolated to what Spain has lived as a whole, as it was confirmed by the Ministry of Spain in the new guidelines proposed for the current academic year 2020-2021.

According to the new addendum to the programme 'Educa en Digital' (Digital Education) from October 2020 by the Ministry of Education and Professional Training, along with the Public Company Red.es ${ }^{14}$, the Government seems to have acknowledged this shortage of technological material launching a programme to promote the technological transformation of education in Spain. This initiative started in the academic year 2020-2021 and is still ongoing. Its objective is to provide half a million devices to educative centres so that they are available to the students. This addendum admitted that:

The closure of schools as a measure to combat the pandemic meant that many vulnerable students were unable to continue their learning process because they did not have the appropriate devices, connectivity, or tools to do so. [Own translation]

This programme also acknowledges that education in Spain requires a process of digital transformation along with the standardisation of online resources, ICT tools for communication and collaboration, availability of devices and connexion to the internet not only for the educators but also for the students in the classroom, and also from home.

\footnotetext{
${ }^{13}$ Fernández, R. (2020). Porcentaje de viviendas equipadas con ordenador en España en 2020, según hábitat. Statista [Percentage of homes equipped with a computer in Spain in 2020] https://es.statista.com/estadisticas/539611/porcentaje-de-viviendas-con-ordenador-segun-habita

${ }_{14}$ BOE (2020c). BOE-A-2020-7682. Convenio entre el Ministerio de Educación y Formación Profesional y la Entidad Pública Empresarial Red.es, M.P., para la ejecución del programa «Educa en digital» en las ciudades de Ceuta y Melilla, mediante acciones para apoyar la transformación digital, Boletín Oficial del Estado 91879 [Agreement between the Ministry of Education and Vocational Training and the Public Business Entity Red.es, M.P., for the implementation of the "Educa en digital" programme in the cities of Ceuta and Melilla, through actions to support digital transformation, Official State Gazette 91879] (2020). https://www.boe.es/diario_boe/txt. php?id=BOE-A-2020-7682
} 


\section{ACCOUNT OF A FORETOLD DEATH}

As a result of the pandemic, the Ministry has launched the educative website 'Aprendo en casa' ${ }^{15}$ (Learning from home), with the aim of channelling quality educational resources, tools and applications available to teachers, families and students. Through this portal multiple links allow access to learning materials developed and implemented by the autonomous regions, private entities and other agents collaborating with this project.

\section{Limitations}

There were some limitations to the present study that affected this research. Firstly, one of the main limitations was site management and school participation during the pandemic. While several schools were contacted, only four, which had previously participated in another study, were willing to participate. At the same time, due to the pandemic restrictions at the time the author was not able to carry out interviews on-site and the teachers requested to be able to answer the questions via online form to have more flexibility. While this still allowed valuable extracted data, it limited the researcher's opportunity to ask further questions or clarifications on certain points. The fact that having schools in different regions of Spain would have been a very interesting analysis is duly acknowledged, unfortunately the Covid-19 lockdown and restrictions made the contact with new schools extremely difficult.

Despite the above limitations, however, the author managed to accomplish the task of providing a general view of the teachers experience during the pandemic and contextualising the regulations that affected this experience.

\section{Conclusion}

While the theory surrounding digital competence has played a big role in the past couple of decades, now the focus is on the actual practice. Digital competence does not only depend on educators but on the infrastructure, which is key. One of the most important learnings of the current events has been the realisation that there is a need for standardised access to technology and accessibility for all students. At the same time, it can be observed that the current curriculum in primary school did not delve into the use of specific ICT use in the classroom and was not prepared for fully virtual teaching, which meant that it was bound to fail in a situation of crisis, such as the current pandemic. The relationship between technology and pedagogy is complex but symbiotic and therefore it cannot be excluded from the guidelines. This research demonstrates that there is indeed a disconnect between legislations, theory and practice. The academic curricula will have to adapt the use of technology to the current needs of the students and society, given that, as it has been demonstrated, the educative centres cannot be excluded from the technological transformation, especially when education needs to be prepared for never-expected eventualities.

The Covid-19 pandemic has resulted in a severe disruption of education. The cancellation of face-to-face teaching along with the initial move to the virtual space limited by the digital platforms of each of the schools, has accelerated the digitalisation process of education. It has shed light on the current digital divide and stressed the importance of technology in education. Nevertheless, while virtual teaching might appear to be a response to the current situation, it is expected to stay for the future. Technologies have evolved greatly in the past 20 years, to the extent that long are the days that technology was just a synonym for computer use in the classroom. The call for an integrated use of technology in the day-to-day classroom to the point that the use of technology becomes seamless is still relevant, and now more than ever. Even though the idea is to go back to on-site teaching, the benefits of online learning have not gone unnoticed and will most likely stay for the foreseeable future, even if it is combined with face-to-face traditional learning.

\section{Declaration of Competing Interest}

None declared.

The protocol for the study was approved by the participants through a verbal informed consent and by filling out the questionnaires. While no separate written consent was obtained from the participants, the questionnaire specified the purpose of the survey and its posterior use in research preserving participant anonymity.

\footnotetext{
${ }^{15}$ https://aprendoencasa.educacion.es/
} 


\section{ALICIA CHABERT}

\section{References}

Bax, S. (2003). CALL-Past, present and future. System, 31(1), 13-28. https://doi.org/10.1016/S0346$251 \mathrm{X}(02) 00071-4$

Corbin, J.M., \& Strauss, A. (2008). Basics of qualitative research: Techniques and procedures for developing grounded theory (3rd ed.). SAGE. https://dx.doi.org/10.4135/9781452230153

Cañón Rodríguez, R., Grande de Prado, M., \& Cantón Mayo, I. (2016). Brecha Digital: Impacto en el desarrollo social y personal. Factores asociados [Digital Gap: Impact on social and personal development. Associated factors]. Tendencias Pedagógicas, 28, 115-132. https://doi.org/10.15366/tp2016.28.009

Celce-Murcia, M., Dörnyei, Z., \& Thurrell, S. (1995). Communicative competence: A pedagogically motivated model with content specifications. Issues in Applied Linguistics, 6, 5-35. https://doi.org/10.5070/L462005216

Chabert, A., \& Agost, R. (2020). Communicative language teaching: Is there a place for L1 in L2 learning? European Journal of Language Policy, 12(1), 55-83. https://doi.org/10.3828/ejlp.2020.4

Chapelle,C.(2009). The relationship between second language acquisition theory and computer-assisted language learning. Modern Language Journal, 93(s1), 741-753. https://doi.org/10.1111/j.1540-4781.2009.00970.x

Chomsky, N. (1965). Aspects of the theory of syntax. MIT Press.

Dörnyei, Z. (2009). The 2010s communicative language teaching in the $21^{\text {st }}$ century. Perspectives, 36(2), 33-43.

Ferrari, A, Punie, Y., \& Redecker, C. (2012). Understanding digital competence in the $21^{\text {st }}$ century: An analysis of current frameworks. In A. Ravenscroft, S. Lindstaedt, C. Delgado Kloos, \& D. Hernández-Leo (Eds.), $21^{\text {st }}$ century learning for $21^{\text {st }}$ century skills (pp. 79-92). Springer. https://doi.org/10.1007/978-3-642-33263-0_7

Ferrari, A. (2012). Digital competence in practice: An analysis of frameworks. Joint Research Centre of the European Commission. European Comisson. https://doi.org/10.2791/82116

Hymes, D. H. (1972). On communicative competence. In J. B. Pride, \& J. Holmes (Eds.), Sociolinguistics. Selected Readings (pp. 269 - 293). Penguin.

Ilomäki, L., Paavola, S., Lakkala, M., \& Kantosalo, A. (2016). Digital competence - An emergent boundary concept for policy and educational research. Education and Information Technologies, 21(3), 655-679. https:// doi.org/10.1007/s10639-014-9346-4

Khan, S. N. (2014). Qualitative research method: Grounded theory. International Journal of Business and Management, 9(11), 224-233. https://doi.org/10.5539/ijbm.v9n11p224

Liu, Y.-C., Kuo, R.-L., \& Shih, S.-R. (2020). Covid-19: The first documented coronavirus pandemic in history. Elsevier Enhanced Reader. Biomedical Journal, 43(4), 328-333. https://doi.org/10.1016/j.bj.2020.04.007

Manegre, M., \& Sabiri, K. A. (2020). Online language learning using virtual classrooms: An analysis of teacher perceptions. Computer Assisted Language Learning. https://doi.org/10.1080/09588221.2020.1770290

Redecker, C., \& Punie, Y. (Eds.). (2017). European framework for the digital competence of educators. European Commission. https://doi.org/10.2760/159770

Serrano Santoyo, A., \& Martínez Martínez, E. (2003). La brecha digital: Mitos y realidades [The digital gap: Myths and reality]. UABC.

Trujillo Sáez, F., Salvadores Merino, C., \& Gabarrón Pérez, Á. (2019). Tecnología para la enseñanza y el aprendizaje de lenguas extranjeras: Revisión de la literatura [Technology for the teaching and learning of foreign languages]. Revista Iberoamericana de Educación a Distancia, 22(1), 153-169. https://doi.org/10.5944/ ried.22.1.22257

van Laar, E., van Deursen, A. J. A. M., van Dijk, J. A. G. M., \& de Haan, J. (2017). The relation between $21^{\text {st }-c e n t u r y}$ skills and digital skills: A systematic literature review. Computers in Human Behavior, 72, 577-588. https:// doi.org/10.1016/j.chb.2017.03.010 